FOLIA HISTORICA CRACOVIENSIA, 22: 2016, s. 47-56

DOI: http://dx.doi.org/10.15633/fhc.2070

Szczepan T. Praśkiewicz OCD

Karmelitański Instytut Duchowości w Krakowie

\title{
Prof. dr hab. Benignus Józef Wanat OCD jako propagator kultu św. Rafała Kalinowskiego
}

Przedmiotem poniższego studium jest zaangażowanie śp. prof. dr. hab. Benignusa J. Wanata OCD w szerzenie kultu św. Rafała Kalinowskiego (1835-1907), powstańca styczniowego i katorżnika Sybiru, później karmelity bosego, odnowiciela zakonu na ziemiach polskich, który jako pierwszy karmelita bosy, po św. Janie od Krzyża, dostąpił w Kościele chwały ołtarzy przez kanonizację ${ }^{1}$. Ojciec Wanat był bowiem twórcą kaplicy i muzeum św. Rafała w klasztorze karmelitów bosych w Czernej k. Krakowa $\mathrm{z}$ okazji jego beatyfikacji w 1983 roku, co sam fachowo opisał' ${ }^{2} \mathrm{Z}$ racji zaś kanonizacji św. Rafała, w 1991 roku, o. Wanat, jako przełożony prowincjalny napisał jego biogram do codziennego wydania dziennika watykańskiego „L'Osservatore Romano"3 oraz skierował do swych podwładnych list okólny, prezentując życie i duchowość świętego, nazywając go „Nową Gwiazdą Karmelu”4.

Redagując poniższy tekst, opieramy się przede wszystkim na wspomnianych publikacjach, a nadto bazujemy na danych $\mathrm{z}$ autopsji, znając wiele szczegółów dotyczących przedmiotowej sprawy jako naoczny świadek.

1 Najlepszą naukową biografią św. Rafała Kalinowskiego pozostaje książka: Cz. Gil, O. Rafał Kalinowski 1835-1907, Kraków 1984. Z późniejszych publikacji warto sięgnąć po album: Sz. T. Praśkiewicz, Św. Rafał Kalinowski wzorem i patronem wspótczesnego człowieka, Kraków 2007.

2 Zob. B. J. Wanat, Kaplica i muzeum bt. Rafała Kalinowskiego w Czernej, „Karmel” (Kraków) (1983) nr 3, s. 43-55; B. J. Wanat, Grób i kaplica św. Rafała Kalinowskiego w Czernej miejscem kultu, [w:] Na drodze do świętości. Rafał Kalinowski powstaniec 1863 i karmelita bosy, red. E. Niebelski, S. Wilk, Lublin 2008, s. 209-220.

3 Zob. B. J. Wanat, La sua vita rappresenta un grande valore del consacrato a Cristo, „L'Osservatore Romano", 16.11.1991, s. 7.

4 Zob. B. J. Wanat, Promieniowanie nowej gwiazdy Karmelu.List okólny prowincjała - o. Benignusa Wanata do klasztorów prowincji Ducha Świętego po kanonizacji Ojca Rafała Kalinowskiego, „Biuletyn Rodziny Karmelitańskiej” (Warszawa) (1991) nr 3, s. 9-17. 


\section{Przedbeatyfikacyjne zaangażowanie o. prof. Wanata w gloryfikację o. Rafała Kalinowskiego i urządzenie kaplicy i muzeum błogosławionego w Czernej}

Nie może umknąć naszej uwadze fakt, że jeszcze na długo przed beatyfikacją Rafała Kalinowskiego o. Wanat, będąc przeorem klasztoru w Czernej (1969-1972) i później - podprzeorem klasztoru w Krakowie (1975-1984), urządzał modlitwy o wyniesienie sługi Bożego na ołtarze, zapraszając na nie m.in. arcybiskupa krakowskiego Karola Wojtyłę, o czym świadczą także fotografie i wpisy do ksiąg pamiątkowych obu wspomnianych klasztorów 5 .

Nadto, pełniąc posługę przeora czerneńskiego, o. Wanat dbał m.in. o pierwotną mogiłę powstańca na cmentarzu zakonnym, z której kilka lat temu usunięto wymowny, brzozowy krzyż, umieszczając na jej wysokości marmurową tablicę na murze klasztornym.

Wiosną 1983 roku, tj. na krótko przed beatyfikacją św. Rafała, prof. Wanat był z ramienia Rady Prowincjalnej odpowiedzialny za urządzenie kaplicy i muzeum o. Kalinowskiego w Czernej. Kaplica została wykonana w miejscu wcześniejszych salek katechetycznych z lewej strony korytarza prowadzącego od głównych drzwi wejściowych do nawy kościoła klasztornego, według planów arch. inż. Józefa Dutkiewicza z Krakowa, przy zaangażowaniu wielu artystów i rzemieślników różnych branż, do których należeli m.in.: mistrz Bronisław Szymiak z synem Ryszardem (prace tynkowe i sztukatorskie); artyści kamieniarze Mieczysław (senior), Mieczysław (junior) i Stanisław Cekierowie (wykonanie epitafium, wsporników, mensy ołtarzowej, portali, parapetów i posadzki z marmuru dębnickiego); artysta stolarz Stanisław Madoń (przygotowanie okien z futrynami i zdobionych drzwi wejściowych) ${ }^{6}$. W marcu 1983 roku prof. Wanat był też organizatorem ekshumacji relikwii przyszłego błogosławionego przez trybunał kościelny i ich ponownego złożenia w nowej trumience i w sarkofagu wykonanym pod jego auspicjami przez artystę Bronisława Chromego z reliefami przedstawiającymi sceny z życia o. Rafała, jak np. jego udział w powstaniu styczniowym, katorgę syberyjską, pobyt w Paryżu, gdzie był wychowawcą bł. Augusta Czartoryskiego, przyjaźń z br. Albertem Chmielowskim i o. Wacławem Nowakowskim - po-

Reprodukcje fotografii oraz faksymile wpisów można znaleźć m.in. w albumach: Sz. T. Praśkiewicz, Oddał życie z miłości. Rafał Kalinowski - Święty z Miasta Papieskiego w wypowiedziach Stugi Bożego Jana Pawła II, Wadowice 2007, s. 22, 52, 55; Sz. T. Praśkiewicz, Święty Rafał Kalinowski wzorem..., dz. cyt., s. 126.

6 Zob. B. J. Wanat, Sanktuarium Św. Rafała Kalinowskiego w Czernej, [w:] Święty Rafał Kalinowski. Księga pamiątkowa, red. Cz. Gil, Sz. T. Praśkiewicz, Kraków 1993, s. 138-139. 
wstańcami i zakonnikami, oraz działalność duszpasterską w Karmelu. Wziął nadto na siebie odpowiedzialność za przygotowanie obrazu beatyfikacyjnego i powierzył to dzieło krakowskiemu malarzowi Jerzemu Kumali. Zamówił u tego samego malarza tryptyk bł. Rafała, przedstawiający go jako powstańca, sybiraka i zakonnika, z przeznaczeniem do kaplicy w Czernej, którą zdobi on po dziś dzień.

Kaplicę bł. Rafała w Czernej, dzieło o. prof. Wanata, poświęcił kard. Anastasio Ballestrero OCD nazajutrz po jego beatyfikacji, tj. 23 czerwca 1983 roku.

Zostawszy w 1984 roku przełożonym prowincjalnym, o. Wanat popierał budowę kościoła karmelitańskiego pw. bł. Rafała w Kluszkowcach (archidiecezja krakowska) i kaplicy pw. tegoż bł. Rafała we Włoszczowicach, w parafii Piotrkowice, prowadzonej przez karmelitów bosych (diecezja kielecka). Sprawił, że do kościoła w Kluszkowcach trafił obraz beatyfikacyjny św. Rafała, użyty podczas ceremonii liturgicznej sprawowanej przez Jana Pawła II 22 czerwca 1983 roku na Błoniach krakowskich. Jego zaś kopia, o nieco mniejszych wymiarach i łukowym zwieńczeniu, wykonana przez tegoż samego artystę Jerzego Kumalę, trafiła do Czernej, gdzie odbiera cześć w ołtarzu kaplicy św. Rafała. Kolejna kopia, z inspiracji o. prof. Wanata, znajduje się w sanktuarium karmelitańskim w Berdyczowie na Ukrainie.

Ślady propagacji kultu św. Rafała przez o. Wanata znajdujemy też w kościele Karmelitów Bosych przy ul. Rakowickiej w Krakowie. Na ścianie nawy głównej, tuż przy prezbiterium, czczona jest ikona, wykonana na jego zamówienie przez malarza Adama Suzina.

\section{Zaangażowanie o. prof. Wanata w propagację przesłania św. Rafała Kalinowskiego z racji jego kanonizacji}

Jako przełożony prowincjalny Polskiej Prowincji Karmelitów Bosych o. prof. Wanat był w 1991 roku gospodarzem uroczystości kanonizacyjnych św. Rafała Kalinowskiego. Postulacja generalna zakonu z Rzymu zleciła Prowincji wykonanie obrazu kanonizacyjnego św. Rafała, w celu umieszczenia go na frontonie Bazyliki św. Piotra w Rzymie w dniu kanonizacji, która nastąpiła 17 listopada 1991 roku. Działając w porozumieniu z radnym i ekonomem prowincji, dr. Mariuszem J. Jaszczyszynem ocD, o. Wanat zaakceptował projekt obrazu przedstawiony przez artystkę Danutę Waberską z Poznania i jej dzieło zostało użyte podczas ceremonii watykańskich. Po kanonizacji obraz trafił do głównego ołtarza wspomnianej wcześniej kaplicy św. Rafała Kalinowskiego we Włoszczowicach. 
Ojciec Wanat, jako wyższy przełożony zakonny, był jednym z 14 koncelebransów Mszy Świętej kanonizacyjnej w Bazylice św. Piotra. Po Eucharystii wraz z Kamilem Maccise ocD, przełożonym generalnym zakonu, podziękował papieżowi Janowi Pawłowi II za kanonizację. A nazajutrz otrzymał od Jana Pawła II jego gratulacje i usłyszał słowa: „Provincia Polonia exaltata est!”. Tak! Bo św. Rafał to przecież pierwszy kanonizowany karmelita bosy po św. Janie od Krzyża!

Niezmordowany w szerzeniu kultu św. Rafała o. Wanat zadbał o to, by prowincja godnie podziękowała papieżowi za dar beatyfikacji i kanonizacji. Janowi Pawłowi II został ofiarowany ozdobny relikwiarz św. Rafała i jego obraz. Kanonizację pierwszego polskiego karmelity bosego o. Benignus upamiętnił nadto, zamawiając u Jerzego Kumali obraz przeznaczony dla Sanktuarium w Czernej. Z jego inicjatywy wezwanie św. Józefa i św. Rafała Kalinowskiego otrzymał nadto nowy klasztor karmelitów bosych w Krakowie-Prądniku Białym (siedziba Kurii Prowincjalnej i wydawnictwa prowincji). W prezbiterium kaplicy tegoż klasztoru obu patronów przywołuje płaskorzeźba dłuta Kazimierza Szczeciny. Przed wejściem zaś do budynku znajduje się posąg współpatrona.

Ojciec Wanat był konsultowany przez Postulację Generalną Zakonu w odniesieniu do wybicia medalu kanonizacyjnego przez firmę Colombo z Mediolanu. Zauważmy, że jest to jedyny medal, który przedstawia św. Rafała en face. Inne nie odchodzą bowiem od przywoływania go z profilu, z piuską na głowie ${ }^{8}$. Warto temu medalowi poświęcić nieco uwagi. Jego przesłanie jest bardzo głębokie. $\mathrm{Na}$ awersie (il. 1) widzimy postać nowego świętego Karmelu z rozłożonymi rękami, a w otoczce czytamy w języku łacińskim: „Św. Rafał Kalinowski 1835-1907. Wpisany w poczet świętych przez Jana Pawła II". Na rewersie zaś (il. 2), wkomponowany w herb zakonu karmelitańskiego, tj. w krzyż z trzema gwiazdkami, napis ma swoją kontynuację i informuje, że stało się to: „w Rzymie, 17 listopada 1991, w czterechsetlecie śmierci św. Jana od Krzyża”. Co więcej, napis, zawsze z otoczki medalu, informuje nas, że nowy święty karmelita bosy: „dla Kościoła jest światłem, dla Karmelu chwałą, dla Polski ozdobą”. Puste zaś pola pod ramionami krzyża karmelitańskiego herbu wypełniają wygrawerowane na medalu z lewej strony rysy Bazyliki św. Piotra i herbu papieskiego Jana Pawła II, z prawej

Zob. Sz. T. Praśkiewicz, Św. Rafał Kalinowski wierny uczeń św. Jana od Krzyża, „L'Osservatore Romano", wyd. pol., (1991) nr 12, s. 28-29.

8 Fotografie tychże medali znajdują się m.in. w: Sz. T. Praśkiewicz, Święty Rafał Kalinowski wzorem..., dz. cyt., s. 131, 167. Tamże, s. 137-168 czytelnik znajdzie zdjęcia wszystkich przywoływanych w artykule dzieł sztuki i wyrazów kultu św. Rafała Kalinowskiego w Polsce i poza jej granicami. 
zaś, przy pięknie zachowanej symetrii - kontury ostrobramskiego sanktuarium Matki Bożej Miłosierdzia i godło Polski. Czyż można było na jednym medalu zawrzeć więcej przesłania?

Czcigodnego o. Benignusa konsultowano też w sprawie upamiętnienia św. Rafała - Patrona Sybiraków na Jasnej Górze. Dedykowano mu tam, w Mauzoleum Sybiraka (na wałach), płaskorzeźbę wykonaną według projektu artystki plastyka Ireny Grabowskiej. Jako historyka sztuki o. Wanta proszono też o sugestie w projektowaniu w 2004 roku nowej polichromii kościoła zbudowanego przez o. Rafała w Wadowicach. W jednej z nisz galerii świętych zakonu upamiętniono tam św. Rafała z miniaturą wadowickiego kościoła w dłoniach. Także przed namalowaniem apoteozy świętych Karmelu w zakrystii Bazyliki św. Teresy w Rzymie przy Kurii Generalnej, na której nie zabrakło postaci św. Rafała, konsultował się z o. Wanatem jej wykonawca, Serafino Melchiore oCD ${ }^{9}$. Słowem, o. prof. Wanat stał się punktem odniesienia licznych inicjatyw szerzących cześć św. Rafała Kalinowskiego nie tylko w Polsce.

\section{Synteza myśli o. prof. Wanata o św. Rafale Kalinowskim}

Syntezę swej myśli o św. Rafale Kalinowskim o. prof. Benignus J. Wanat zawarł w cytowanym już liście okólnym Promieniowanie nowej Gwiazdy Karmelu. Nazwał w nim tego swego zakonnego współbrata: „wiernym uczniem św. Jana od Krzyża, miłośnikiem Matki Bożej, czcicielem św. Józefa i patriotą kochającym Ojczyznę nawet za cenę życia”.

W kanonizacji św. Rafała widział dla swoich współbraci karmelitów bosych, dla których był w Polsce najwyższym przełożonym, wezwanie do odnowy i do twórczej wierności charyzmatowi Karmelu. To zaś winno się przejawiać w wierności życiu modlitwy i apostolatu, w wierności życiu wspólnotowemu, w odnowieniu konsekracji zakonnej, w podejmowaniu ascezy i ewangelicznego wyrzeczenia i w promowaniu postaw patriotycznych ${ }^{10}$.

Ojciec Benignus wskazał nadto zasadnicze kierunki posłannictwa św. Rafała, tj.: odrodzenie moralne i duchowe człowieka, prekursorskie zaangażowanie ekumeniczne, odnowienie życia zakonnego na ziemiach polskich i ukierunkowanie

\footnotetext{
9 Zob. Basilica di Santa Teresa a Roma. La Sagrestia di Fra Serafino, Roma 2002.

10 Zob. B. J. Wanat, Promieniowanie..., dz. cyt., s. 12-15.
} 
ku powrotowi Karmelu na Wschód, posługę spowiedzi i kierownictwa duchowego, szerzenie kultu maryjnego i nabożeństwa szkaplerznego ${ }^{11}$.

W podsumowaniu należy więc stwierdzić, że w zmarłym przed dwoma laty śp. o. prof. dr. hab. Benignusie J. Wanacie mieliśmy prawdziwego czciciela i propagatora kultu św. Rafała Kalinowskiego, naszego rodaka, który jako pierwszy karmelita bosy po św. Janie od Krzyża został wpisany w poczet świętych. Potrafił on - jak to przypominał o. Wanat - zawsze żyć miłością, mimo że przyszło mu żyć w czasach o wiele trudniejszych niż nasze: w szkole nie mógł się uczyć w języku ojczystym, na ulicach swego miasta od dziecka widział wojskowe oddziały zaborcy; gimnazjum, w którym się kształcił, znajdowało się naprzeciw klasztoru zamienionego na więzienie polityczne, z którego wychodziło się albo na szubienicę, albo na Sybir; sam doświadczył dziesięcioletniej katorgi syberyjskiej, po której był skazany na emigrację na Zachodzie. Udowodnił, że by żyć ewangeliczną miłością, nie trzeba oczekiwać nadejścia „lepszych czasów”, bo do jej praktykowania „wszystkie czasy są dobre”. I sam wyjaśnił, gdzie znajdował siłę: „w ucieczce do sakramentów świętych i w modlitwie” ${ }^{12}$.

Dlatego jest czymś naturalnym, że w sanktuarium czerneńskim, miejscu spoczynku relikwii św. Rafała i szczególnego jego kultu, o. prof. Benignusa Wanata, tegoż kultu propagatora par eccellence, upamiętnia m.in. jego portret na jednym z klasztornych korytarzy, w tzw. galerii prowincjałów (il. 3). Nadto, Jerzy Kumala, który na zamówienie o. Benignusa upamiętnił na płótnie kanonizację św. Rafała, o czym już wspominaliśmy, na symetrycznym obrazie przywołującym koronację Czerneńskiej Madonny Szkaplerznej (1998) uwiecznił o. Benignusa z koroną przeznaczoną dla Tej, która według św. Rafała Kalinowskiego winna być obecna w życiu każdego karmelity bosego „zawsze i we wszystkim” ${ }^{13}$.

Słusznie też na pośmiertnym obrazku upamiętniającym o. Benignusa przywołano słowa jego samego:

${ }_{11}$ Zob. B. J. Wanat, Promieniowanie..., dz. cyt., s. 15-16.

12 J. Kalinowski (Rafał od św. Józefa), Listy, t. 1, cz. 2, wyd. Cz. Gil, Lublin 1978, s. 149 (list nr 297 z 11.01.1875). Por. B. J. Wanat, Promieniowanie..., dz. cyt., s. 13.

13 Św. Rafał Kalinowski, Maryja zawsze i we wszystkim, red. J. Krawczyk, Poznań 2011. 
Przypominanie historycznych postaci, konsekrowanych i oddanych Bogu i służbie Kościoła stanowi ważny element programu formacyjnego poznania historii Karmelu, która jest mistrzynią życia. Na przykładzie konkretnych wzorów historia uczy miłości Boga i ludzi, Kościoła i Zakonu. Buduje i zachęca gorliwością życia. Upomina i przestrzega przed niebezpieczeństwami. Prowadzi do pragmatyzmu na drodze wierności ideałom $^{14}$.

\section{Abstrakt}

Artykuł przedstawia zaangażowanie śp. prof. dr. hab. Benignusa Józefa Wanata OCD w szerzenie kultu św. Rafała Kalinowskiego (1835-1907), powstańca styczniowego i katorżnika Sybiru, później karmelity bosego, odnowiciela zakonu na ziemiach polskich, który jako pierwszy karmelita bosy, po św. Janie od Krzyża, dostąpił w Kościele chwały ołtarzy przez kanonizację. Ojciec Wanat był twórcą kaplicy i muzeum św. Rafała w klasztorze karmelitów bosych w Czernej koło Krakowa z okazji jego beatyfikacji w 1983 roku. Z kolei z okazji kanonizacji św. Rafała w 1991 roku, będąc przełożonym prowincjalnym, o. Wanat opublikował jego biogram w dzienniku watykańskim „L'Osservatore Romano”, współpracował $\mathrm{z}$ artystami wykonującymi podobizny świętego oraz skierował do polskich karmelitów bosych list okólny, prezentując życie i duchowość św. Rafała, nazwanego „Nową Gwiazdą Karmelu”.

Autor artykułu czerpie wiedzę z publikacji oraz z autopsji, znając wiele szczegółów dotyczących przedmiotowej sprawy jako naoczny świadek.

${ }^{14}$ B. J. Wanat, Wprowadzenie, [w:] K. Furmanik, Ksiega Zmarłych Ojców i Braci karmelitów Bosych Prowincji polskiej i Prowincji Krakowskiej pw. Ducha Świętego 1881-1998, Kraków 1998, s. 5. 


\section{Abstract \\ Fr Prof. Benignus Józef Wanat OCD as a promoter of the worship of St Rafał Kalinowski}

This article shows the commitment of the late Fr. prof. dr. hab. Benignus J. Wanat OCD in spreading the cult of St. Raphael Kalinowski (1835-1907), the January insurrectionist and convict who was transported to Siberia, later a Discalced Carmelite and restorer of this Order on Polish soil, and the first Discalced Carmelite who attained canonisation in the Church, since St. John of the Cross. On the occasion of St Raphael's beatification in 1983, Father Wanat was a founder of the chapel and museum dedicated to the Saint and located at the monastery of the Discalced Carmelites in Czerna near Kraków. Also, on the occasion of the canonization of Saint Raphael in 1991, while provincial superior, Father Wanat published his biography in the Vatican newspaper „L'Osservatore Romano", collaborated with artists depicting the Saint and referred a circular letter to the Polish Carmelite Province presenting the life and spirituality of St. Raphael, entitled „New Star of Carmel".

The author draws on knowledge from publications and personal cooperation, having known many of the details of the case through first-hand witness. 


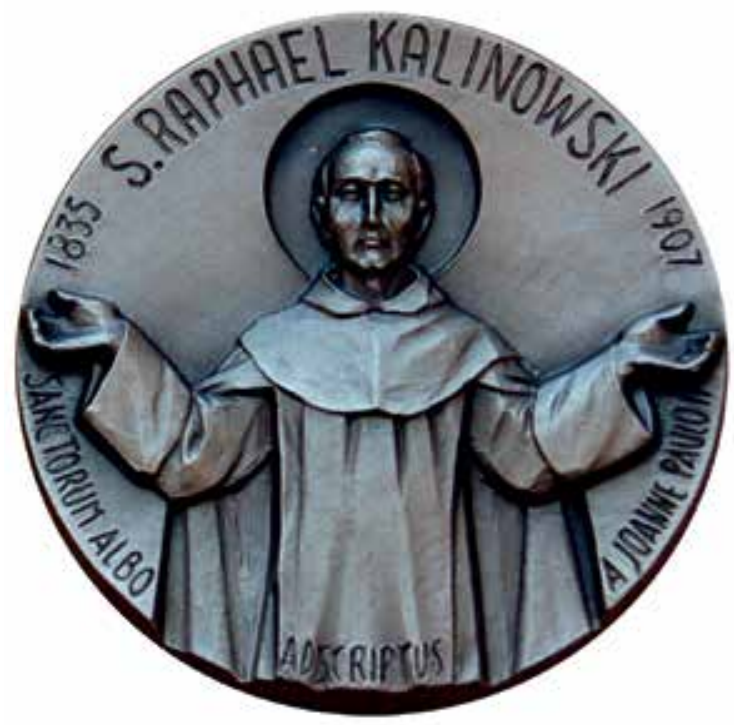

1. Medal kanonizacyjny św. Rafała Kalinowskiego wybity przez firmę Colombo w Mediolanie (awers)

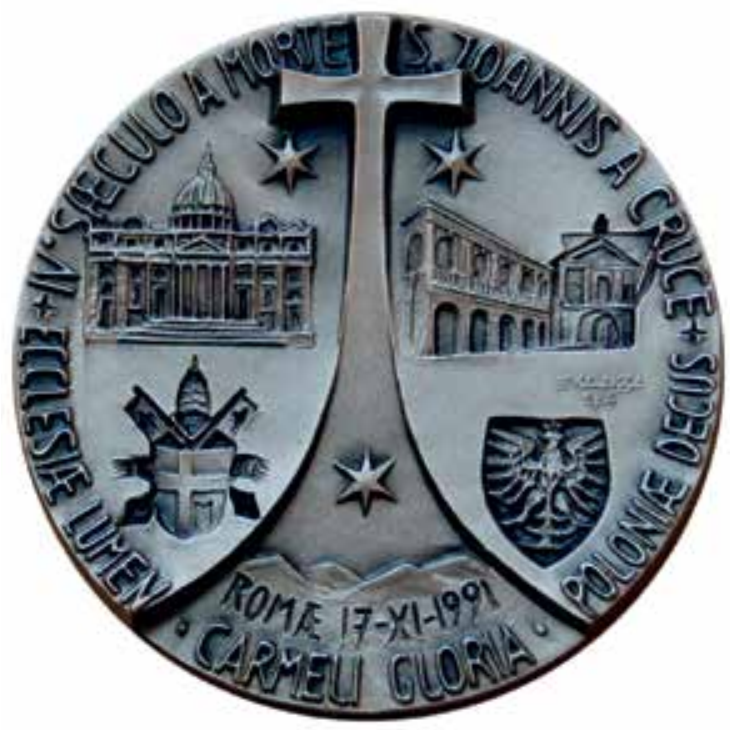

2. Rewers medalu kanonizacyjnego 


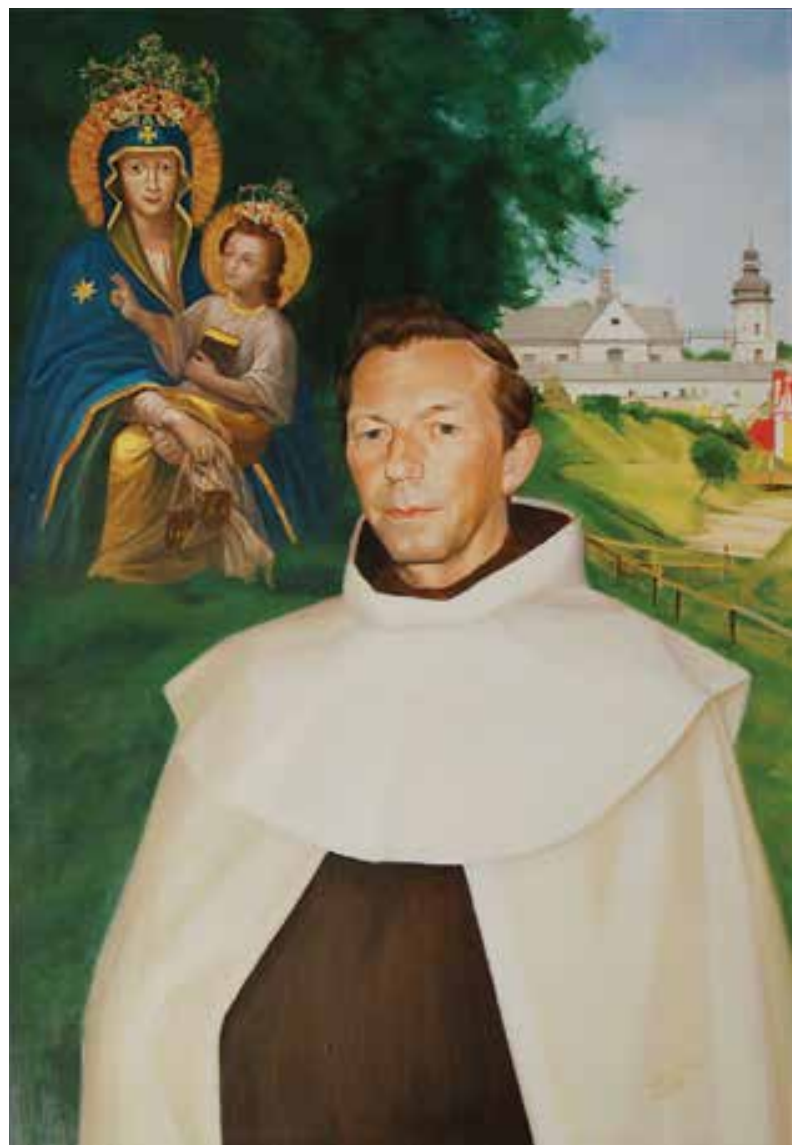

3. Portret o. prof. Benignusa J. Wanata jako przełożonego prowincjalnego (mal. Michaela od Boga Wszechmogącego Kornecka) 